[Agr. Biol. Chem., Vol. 33, No. 5, p. 711 717, 1969]

\title{
Studies on the Low Temperature Fermentation
}

\author{
Part II. Amino Acid Formation by Facultative \\ Psychrophilic Bacterium*
}

\author{
By Koichi Ogata, Nobuo Kato, Masahiro Osugi \\ and Tatsurokuro Tochikura \\ Department of Agricultural Chemistry, Kyoto University, Kyoto \\ Received August 16, 1968
}

\begin{abstract}
With the Brevibacterium sp. P 145 isolated from soil, the effect of incubation temperature on the extracellular amino acid accumulation has been examined from cultural and enzymological points of view. The strain was found to accumulate L-glutamic acid up to $5.88 \mathrm{mg} / \mathrm{ml}$ and L-alanine $0.38 \mathrm{mg} / \mathrm{ml}$ at $5^{\circ} \mathrm{C}$, whereas it formed $0.21 \mathrm{mg} / \mathrm{ml}$ of L-glutamic acid and $2.54 \mathrm{mg} / \mathrm{ml}$ of L-alanine at $28^{\circ} \mathrm{C}$.

The accumulation of L-alanine in the medium at $28^{\circ} \mathrm{C}$ seemed to be related to the thiamine requirement of the strain. In the case of thiamine deficiency, L-alanine was the main product in the culture at $28^{\circ} \mathrm{C}$. When the incubation temperature was abruptly shifted from $28^{\circ}$ to $5^{\circ} \mathrm{C}$ or from $5^{\circ}$ to $28^{\circ} \mathrm{C}$, the amino acid accumulation was also changed to that of the final temperature. L-Alanine dehydrogenase existed even in the cells grown at $5^{\circ} \mathrm{C}$ but was not active at this low temperature. These results were in accord with the informations obtained from cultural experiments.
\end{abstract}

In the preceding paper, ${ }^{11}$ the authors have reported that a psychrophilic bacterium, Brevibacterium sp. P 145 isolated from soil, formed glutamic acid at low temperature and was auxotrophic only at high temperature.

It has often been assumed that the rate of individual metabolic process decreases at the same rate as the growth rate, as the temperature decreases from the optimum. However, increased production of metabolites by microorganisms at suboptimum temperature are known in some cases as pigment ${ }^{2,31}$

\footnotetext{
* A part of this work was presented at the meeting of the Kansai Division of Agricultural Chemical Society of Japan, Kobe, May, 21, 1968.

1) K. Ogata, T. Tochikura, N. Kato and M. Osugi, Agr. Biol. Chem., 33, 704 (1969).

2) R.P. Williams, M. E. Goldschmidt and C. L. Gott, Biochem. Biophys. Res. Commum., 19, 177 (1965).

3) R. L. Uffen and E. Canale-Parola, Can. J. Microbiol., 12, 590 (1966).
}

and dextran production. Owen and Johnson $^{5}$ ' reported with Penicillium chrysogenum that the best temperature for mycelium-production was at $30^{\circ} \mathrm{C}$, while at $20^{\circ} \mathrm{C}$ the penicillin productivity was the best. Similar phenomenon was utilized to obtain high yields of citric acid by Aspergillus niger. ${ }^{61}$ Kosano and Yamada $^{7}$ reported that the ratio of two fermentation products, glutamic acid and lactic acid, was affected by the temperatures for seed-culture and main-culture.

In the present paper, the conversion of fermentation products by incubation temperature for Brevibacterium sp. P 145 is decreased,

4) L. K. Dunican and H. W. Seeley, J. Bacteriol, 86, 1079 (1963).

5) S. P. Owen and M. J. Johnson, Appl. Microbiol., 3, 375 (1955).

6) Y. Noguchi and O. Arao, J. Ferment. Technol. Japan, 38, 491 (1960).

7) Y. Kosano and K. Yamada, Nippon Nogeikagaku Kaishi, 37, 591 (1961). 
and the nature of this conversion is discussed on the basis of the results of cultural and enzymological experiments.

\section{MATERIALS AND METHODS}

Microorganism. A facultative psychrophilic bacterium, Brevibacterium sp. P 145 was used throughout the experiment. The organism has a broad growth temperature range, i.e., from $0^{\circ}$ to $37^{\circ} \mathrm{C}$.

Medium. The basal medium: glucose, $30 \mathrm{~g}$; urea, $4 \mathrm{~g} ; \mathrm{NH}_{4} \mathrm{Cl}, 1 \mathrm{~g} ; \mathrm{K}_{2} \mathrm{HPO}_{4}, 2 \mathrm{~g} ; \mathrm{KH}_{2} \mathrm{PO}_{4}, 1 \mathrm{~g} ; \mathrm{MgSO}_{4}$. $7 \mathrm{H}_{2} \mathrm{O}, 0.5 \mathrm{~g}$; phenol red, $2 \mathrm{mg}$; in $1000 \mathrm{ml}$ of tap water. The $\mathrm{pH}$ was adjusted to 7.4. The urea solution was fed not only to supply nitrogen but also to maintain the medium slightly alkaline.

Cultivation. One loopful organism from the slope culture was inoculated into a test tube containing $5 \mathrm{ml}$ of the basal medium. The cultured broth of $5 \mathrm{ml}$ was inoculated into $100 \mathrm{ml}$ of the medium in a $500 \mathrm{ml}$ shaking flask. The incubation was carried out at various temperature on a reciprocal shaker (at 130 reciprocation per min). At intervals, a part of the cultured broth was withdrawn and centrifuged, and the supernatant solution was subjected to chemical analysis.

Analysis. For the quantitative analysis of glutamic acid and alanine, the paper chromatographic method as described previously ${ }^{11}$ was adopted. Glucose was determined both by Somogyi-Nelson's method ${ }^{8}$ and by Bertrand's method. ${ }^{9}$

The growth of the organism was routinely estimated by measuring the optical density at $610 \mathrm{~m} \mu$ of 10 -fold diluted broth. The dry weight of cells was computed from the optical density, using a standard curve prepared with the culture grown exponentially at $5^{\circ} \mathrm{C}$ in a peptone-supplemented basal medium.

Protein was determined by the method of Lowry et al.10!

Preparation of cell-free extract. The dialyzed cellfree extract was subjected to the assays of L-glutamic acid dehydrogenase and L-alanine dehydrogenase.

8) M. Somogyi, J. Biol. Chem., 160, 61, 74 (1945).

9) G. Bertrand, Bull. Soc. Chem. Paris, 35, 1285 (1906).

10) O. H. Lowry, N. J. Rosenbrough, A. L. Forr and R. T. Randall, J. Biol. Chem., 193, 265 (1951).
After 4 and 2 days at $5^{\circ}$ and $28^{\circ} \mathrm{C}$, respectively, the cells were harvested by centrifugation. The cells were washed twice with $0.85 \% \mathrm{NaCl}$ solution, then suspended in $\mathbf{M} / 15$ potassium phosphate buffer, $\mathrm{pH}$ 7.8. The cell-free extract was prepared by exposing the suspension to Kaijo Denki Ultrasonic Oscillator $(19 \mathrm{~Hz}$, for $30 \mathrm{~min})$ and the cell debris was removed by centrifugation at $12,000 \times g$ for $30 \mathrm{~min}$. The extract thus obtained was dialyzed overnight against M/15 potassium phosphate buffer, $\mathrm{pH} 7.8$, containing $0.05 \%$ 2-mercaptoethanol, at $5^{\circ} \mathrm{C}$.

Enzyme assay. The enzyme activities were determined by measuring the change in optical density at $340 \mathrm{~m} \mu$ according to the method reported by Olson and Anfinsen.11) The increase or decrease of the optical density at $340 \mathrm{~m} \mu$ was followed in a HitachiPerkin-Elmer Model 139 Spectrophotometer.

Specific activities of L-glutamic acid and L-alanine dehydrogenases were expressed as $d E$ per gram of protein, where $\Delta E$ was the increase or decrease of optical density of NADH or NADPH at $5^{\circ}$ and $28^{\circ} \mathrm{C}$ during the initial $1 \mathrm{~min}$ incubation.

\section{RESULTS AND DISCUSSION}

\section{Identification of L-glutamic acid and L-alanine}

L-Glutamic acid and L-alanine accumulated in the cultured broth were identified as des-

TABLE I. IDENTIFICATION OF L-GLUTAMIC ACID AND L-ALANINE

\begin{tabular}{|c|c|c|c|c|}
\hline \multirow{3}{*}{ Sample } & & \multicolumn{2}{|c|}{ Method } & \\
\hline & \multicolumn{2}{|c|}{ Chromatographic } & \multicolumn{2}{|c|}{ Biological } \\
\hline & $\begin{array}{l}\text { Glutamic } \\
\text { acid } \\
\mathrm{mg} / \mathrm{ml}\end{array}$ & $\begin{array}{c}\text { Alanine } \\
\mathrm{mg} / \mathrm{ml}\end{array}$ & $\begin{array}{l}\text { L-Glutamic } \\
\text { acid } \\
\mathrm{mg} / \mathrm{ml}\end{array}$ & $\begin{array}{l}\text { L-Alanine } \\
\mathrm{mg} / \mathrm{ml}\end{array}$ \\
\hline $1 *$ & 5.50 & 0.72 & 5.20 & 1.00 \\
\hline $2 * *$ & 0.07 & 2.54 & 0.09 & 2.25 \\
\hline
\end{tabular}

* Broth cultured at $5^{\circ} \mathrm{C}$ for 10 days.

** Broth cultured at $28^{\circ} \mathrm{C}$ for 4 days.

The L-amino acids were determined by paper chromatographic and biological methods. The biological methods were the manometric method using L-glutamic acid decarboxylase of $E$. coli for L-glutamic acid and the microbiological method using Leuco. citrovorum, for L-alanine.

11) J.A. Olson and C. B. Anfinsen, J. Biol. Chem., 197, 67 (1952). 
cribed below. For the identification of Lglutamic acid, the manometric method using L-glutamic acid decarboxylase prepared from Escherichia coli $^{121}$ was employed. For L-alanine, microbiological analysis using Leuconostoc citrovorum $^{131}$ was carried out. Results were summarized in Table I. The values obtained enzymatically or biologically coincided to those measured by paper chromatography.

\section{Cultural condition}

Some cultural conditions favoring the accumulation of L-glutamic acid at $5^{\circ} \mathrm{C}$ were examined.

l) Growth substance. Various growth promoting substances shown in Table II were added to the basal medium. It was demonstrated that peptone and meat extract gave a considerable stimulative effect on both growth and L-glutamic acid accumulation, whereas yeast extract and casamino acid did not show any noticeable effect.

TABLE II. EFFeCt OF GROWTH SUBSTANCE ON GLUTAMIC ACID Formation at $5 \% \mathrm{C}$

$\begin{array}{lcccc}\begin{array}{l}\text { Growth } \\ \text { substance }\end{array} & (g) & \begin{array}{c}\text { Growth } \\ \mathrm{mg} / \mathrm{ml}\end{array} & \overbrace{\mathrm{mg} / \mathrm{ml}}^{\text {Glutamic acid }} & \begin{array}{c}\text { Com- } \\ \text { parison }\end{array} \\ \text { None } & & 2.0 & 0.72 & 1.00 \\ \text { Peptone } & 0.2 & 3.8 & 3.90 & 5.41 \\ \text { Yeast extract } & 0.2 & 2.7 & 1.14 & 1.58 \\ \text { Meat extract } & 0.2 & 4.3 & 3.78 & 5.25 \\ \text { Casamino acid } & 0.2 & 2.8 & 1.88 & 2.61\end{array}$

Cultures were performed with addition of each growth substance $(0.2 \%)$ to basal medium at $5^{\circ} \mathrm{C}$ for 8 days.

2) Glucose concentration. The effect of glucose concentration in the medium on the amino acid accumulation and the growth was investigated. The results are shown in Table III. It was observed that the optimum concentration of glucose was $3 \%$ and that

12) V.A. Najjar and J. Fisher, J. Biol. Chem., 206, 215 (1954).

13) H. E. Sauberlich, ibid., 177, 545 (1949). the higher concentration caused the lower yield of L-glutamic acid as well as growth.

TABLE III. EFFECT OF GLucose Concentration on Glutamic acid Formation at $5^{\circ} \mathrm{C}$

Glucose $(9)$
3.0
5.0
7.0
10.0

\begin{tabular}{|c|c|c|}
\hline \multicolumn{2}{|c|}{ Growth } & Glutamic \\
\hline 0 & 10 days & $(\mathrm{mg} / \mathrm{ml})$ \\
\hline 0.2 & 4.3 & 5.88 \\
\hline 0.2 & 3.8 & 4.08 \\
\hline 0.2 & 1.2 & 0.86 \\
\hline 0.2 & 1.4 & 1.77 \\
\hline
\end{tabular}

Cultures were performed with the medium supplemented with $0.2 \%$ peptone at $5^{\circ} \mathrm{C}$ for 8 days.

\section{Effect of temperature}

Five milliliters of the broth cultured in the basal medium for 3 days at $5^{\circ} \mathrm{C}$ were inoculated into $100 \mathrm{ml}$ of the medium in a 500-ml flask.

The culture was incubated at $5^{\circ}, 15^{\circ}$ or $28^{\circ} \mathrm{C}$. As shown in Table IV, the highest extent of growth was obtained at $15^{\circ} \mathrm{C}$. Although the maximum growth extent reached most rapidly at $28^{\circ} \mathrm{C}$ (after 2 days), the cell yields were lower than those at other temperatures. As regard to the amino acid accumulation at $5^{\circ} \mathrm{C}$, L-glutamic acid was mainly accumulated and L-alanine was only slightly, whereas at $28^{\circ} \mathrm{C}$, the main product was L-alanine but not L-glutamic acid. At $15^{\circ} \mathrm{C}$, both amino acids were accumulated in the same extent which was almost the mean of those observed at $5^{\circ}$ and $28^{\circ} \mathrm{C}$.

\section{TABLE IV. EFFect OF Temperature} ON AMINO ACID FORMATION

$\begin{array}{llllll}\begin{array}{l}\text { Incubation } \\ \text { temperature } \\ { }^{\circ} \mathrm{C}\end{array} & \mathrm{mg} / \mathrm{ml} & \begin{array}{c}\text { after } \\ \text { (day) }\end{array} & \begin{array}{c}\text { Glu- } \\ \text { tamic } \\ \text { acid } \\ \mathrm{mg} / \mathrm{ml}\end{array} & \begin{array}{c}\text { Ala- } \\ \text { nine }\end{array} & \begin{array}{c}\text { after } \\ \text { (day) }\end{array} \\ 5 & 5.2 & 4 & 5.88 & 0.38 & 8 \\ 15 & 5.7 & 3 & 1.88 & 1.00 & 6 \\ 28 & 4.0 & 2 & 0.21 & 2.54 & 4\end{array}$

Cultures were performed with the medium supplemented with $0.2 \%$ peptone. 


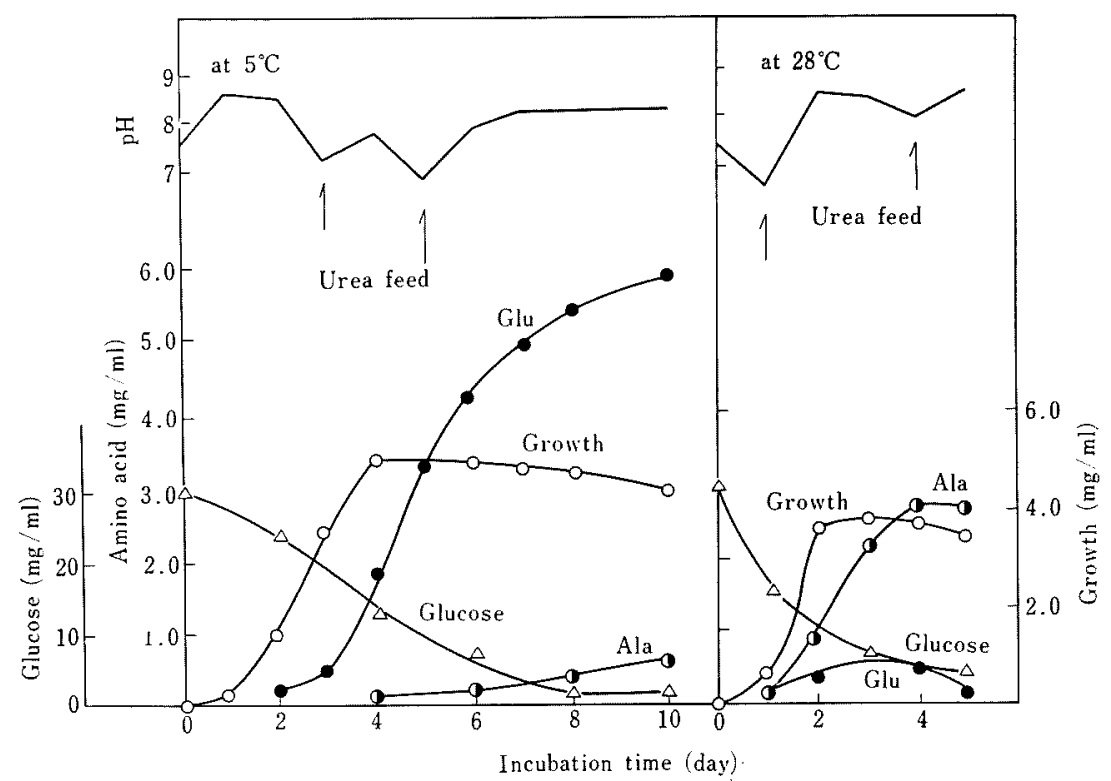

FIG. 1. Time-Course of Amino Acid Formation at $5^{\circ}$ and $28^{\circ} \mathrm{C}$.

Medium contained $30 \mathrm{~g}$ of glucose, $4 \mathrm{~g}$ of urea, $1 \mathrm{~g}$ of $\mathrm{K}_{2} \mathrm{HPO}_{4}, 2 \mathrm{~g}$ of $\mathrm{KH}_{2} \mathrm{PO}_{4}, 0.5 \mathrm{~g}$ of $\mathrm{MgSO}_{4} \cdot 7 \mathrm{H}_{2} \mathrm{O}, 2 \mathrm{~g}$ of peptone and $2 \mathrm{mg}$ of phenol red in $1000 \mathrm{ml}$ of tap water $(\mathrm{pH} 7.4)$.

The time course of amino acid accumulation at $5^{\circ}$ and $28^{\circ} \mathrm{C}$ is presented in Fig. 1 .

Effect of the addition of methionine, thiamine and biotin

As described in the preceding paper," Brevibacterium sp. $\mathrm{P} 145$ requires methionine essentially, and thiamine and biotin accessorily.

Relationship between productivity of amino acid and nutritional requirement of the organism was investigated. In the experiment, the inoculum was prepared from the washed cells grown fully in the basal medium at $5^{\circ} \mathrm{C}$. When $\mathrm{DL}$-methionine $(200 \mu \mathrm{g} / \mathrm{ml})$ was added in the basal medium the growth was rather lower. Although the yields of the amino acids were lower compared with the control, main products were consistently Lglutamic acid at $5^{\circ} \mathrm{C}$ and L-alanine at $28^{\circ} \mathrm{C}$. Biotin did not affect the amino acid formation. On the other hand, the L-alanine accumulation at $28^{\circ} \mathrm{C}$ seemed to be influenced in some extent by the concentration of thiamine added. If the excess thiamine, (5.0 $\mu \mathrm{g} / \mathrm{ml}$ ) was added to the basal medium supplemented with methionine, the rate of L-alanine accumulation decreased. In the case of thiamine deficiency, L-alanine was the main product of the culture at $28^{\circ} \mathrm{C}$ (Table V).

In the alanine accumulation, thiamine might play an important role. Tanaka and Kinoshita ${ }^{14}$ reported with Bacillus lentus that the alanine production increased with the suboptimum concentration of thiamine even if the biotin level was high. The fact that alanine was accumulated $28^{\circ} \mathrm{C}$ by the strain P 145 seemed to agree with the accessory requirement of thiamine at $28^{\circ} \mathrm{C}$ as the case of $B$. lentus.

14) K. Tanaka and S. Kinoshita, Nippon Nogeikagaku Kaishi, 34, 600 (1960). 
TABLE V. EFFect of Methionine, Biotin and Thiamine on Amino acid Formation

\begin{tabular}{|c|c|c|c|c|c|c|}
\hline \multirow{3}{*}{$\begin{array}{l}\text { Basal } \\
\text { medium }\end{array}$} & \multirow{3}{*}{ Addition } & \multirow{3}{*}{$(\mu \mathrm{g} / \mathrm{ml})$} & \multicolumn{4}{|c|}{ Culture condition } \\
\hline & & & \multicolumn{2}{|c|}{ at $28^{\circ} \mathrm{C}$ for 4 days } & \multicolumn{2}{|c|}{ at $5^{\circ} \mathrm{C}$ for 10 days } \\
\hline & & & $\begin{array}{l}\text { Glutamic } \\
\text { acid }\end{array}$ & Alanine & $\begin{array}{l}\text { Glutamic } \\
\text { acid }\end{array}$ & Alanine \\
\hline & & & \multicolumn{2}{|c|}{$\mathrm{mg} / \mathrm{ml}$} & \multicolumn{2}{|c|}{$\mathrm{mg} / \mathrm{ml}$} \\
\hline GU & (Basal medium) & & \multicolumn{2}{|c|}{ (no growth) } & 0.70 & $\operatorname{tr}$ \\
\hline GU & DL-Methionine & 20 & $\operatorname{tr}$ & 0.68 & 0.62 & $\operatorname{tr}$ \\
\hline $\mathrm{GU}$ & DL-Methionine & 200 & $\operatorname{tr}$ & 0.67 & 0.90 & $\operatorname{tr}$ \\
\hline GU & DL-Methionine & 2000 & $\operatorname{tr}$ & 0.72 & 0.80 & $\operatorname{tr}$ \\
\hline GUM & Biotin & 0.005 & $\operatorname{tr}$ & 0.60 & 0.88 & $\operatorname{tr}$ \\
\hline GUM & Biotin & 0.05 & $\operatorname{tr}$ & 0.72 & 0.60 & $\operatorname{tr}$ \\
\hline GUM & Biotin & 0.5 & $\operatorname{tr}$ & 0.80 & 0.70 & $\operatorname{tr}$ \\
\hline GUM & Thiamine $\mathrm{HCl}$ & 0.5 & $\operatorname{tr}$ & 0.60 & 0.98 & $\operatorname{tr}$ \\
\hline GUM & Thiamine $\mathrm{HCl}$ & 1.0 & $\operatorname{tr}$ & 0.60 & 0.90 & $\operatorname{tr}$ \\
\hline GUM & Thiamine $\mathrm{HCl}$ & 5.0 & $\operatorname{tr}$ & $\operatorname{tr}$ & 1.00 & $\operatorname{tr}$ \\
\hline GUM & Peptone & 2000 & 0.60 & 2.34 & 4.61 & 0.70 \\
\hline
\end{tabular}

The basal medium mentioned in materials and methods symbolized by GU and the basal medium supplemented with DL-methionine was symbolyzed by GUM. tr: trace.

\section{Effect of abrupt temperature shift on amino acid} formation

This series of experiment was made to establish whether, after temperature shifted, the amino acid accumulation by the organism was changed or not. Brevibacterium sp. P 145 was cultured aerobically in the peptonesupplemented medium at $5^{\circ}$ and $28^{\circ} \mathrm{C}$. After these cultures reached the certain stages, the temperature was rapidly changed to $28^{\circ}$ and $5^{\circ} \mathrm{C}$ respectively. Figure 2 represents the effect of the temperature shift from $5^{\circ}$ to $28^{\circ} \mathrm{C}$ (a) and from $28^{\circ}$ to $5^{\circ} \mathrm{C}(\mathrm{b})$ on the accumulations of L-glutamic acid and L-alanine. Although L-alanine was scantly produced at $5^{\circ} \mathrm{C}$, after the shift from $5^{\circ}$ to $28^{\circ} \mathrm{C}$ the production of L-alanine occurred abruptly. As to L-glutamic acid, the accumulation continued even after the shift to $28^{\circ} \mathrm{C}$, although the rate of the formation was considerably depressed comparing with the culture at $5^{\circ} \mathrm{C}$. In the case of shift down (from $28^{\circ}$ to $5^{\circ} \mathrm{C}$ ) the formation of L-alanine stopped completely and L-glutamic acid was produced progressively. From these results, it is assumed that the conversion of main products by changing the incubation temperature reflects the sub-

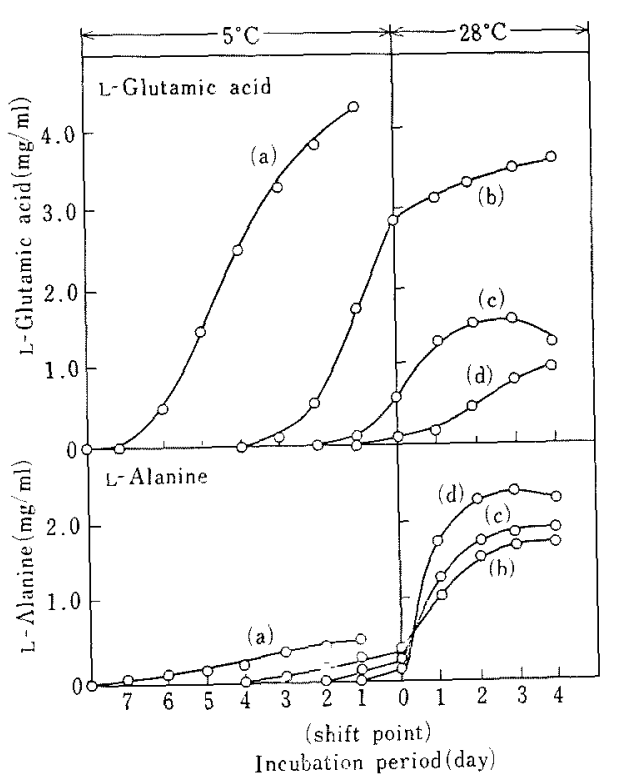

FIG. 2-a. Effect of Abrupt Temperature Shift from $5^{\circ}$ to $28^{\circ} \mathrm{C}$ on the Formation of Amino Acid.

Medium was the same as described in Fig. 1.

(a): Culture was performed at $5^{\circ}$ for 8 days.

(b): Incubation temperature was shifted after 4 days culture at $5^{\circ} \mathrm{C}$.

(c): Incubation temperature was shifted after 2 days culture at $5^{\circ} \mathrm{C}$.

(d): Incubation temperature was shifted after 1 day culture at $5^{\circ} \mathrm{C}$. 


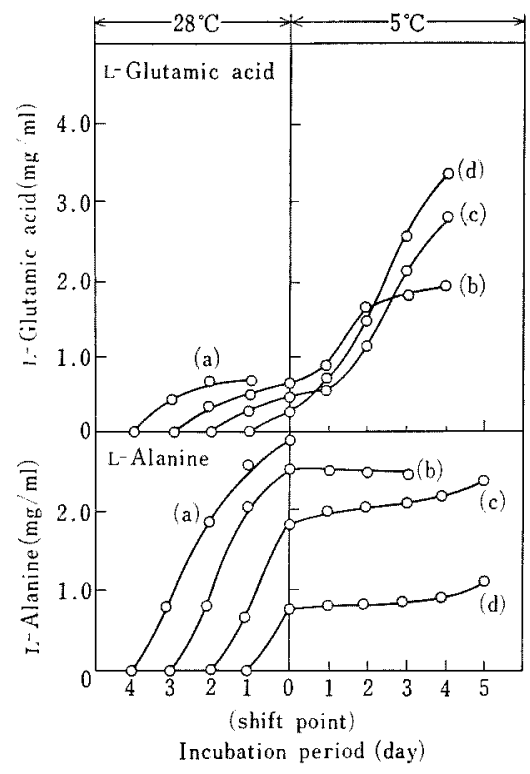

FIG. 2-b. Effect of Abrupt Temperature Shift from $28^{\circ}$ to $5^{\circ} \mathrm{C}$ on the Formation of Amino Acid.

Medium was the same as described in Fig. 1.

(a): Culture was performed at $28^{\circ} \mathrm{C}$ for 4 days.

(b): Incubation temperature was shifted after 3 days culture at $28^{\circ} \mathrm{C}$.

(c): Incubation temperature was shifted after 2 days culture at $28^{\circ} \mathrm{C}$.

(d): Incubation temperature was shifted after 1 day culture at $28^{\circ} \mathrm{G}$.

stantial difference of metabolic processes at each temperature. Such alteration by incubation temperature is remarkable especially in $\mathrm{L}$-alanine formation. It is presumed that the organism has a cold-sensitive step in the $\mathrm{L}$ alanine biosynthesis.

Effect of temperature on L-glutamic acid and Lalanine dehydrogenase activities

In order to explain enzymatically the conversion of fermentation by incubation temperature, the presence and activity of L-glutamic acid and L-alanine dehydrogenases in the cells which might be the last steps of biosynthesis of L-glutamic acid and L-alanine, were examined. As shown in Fig. 3, the

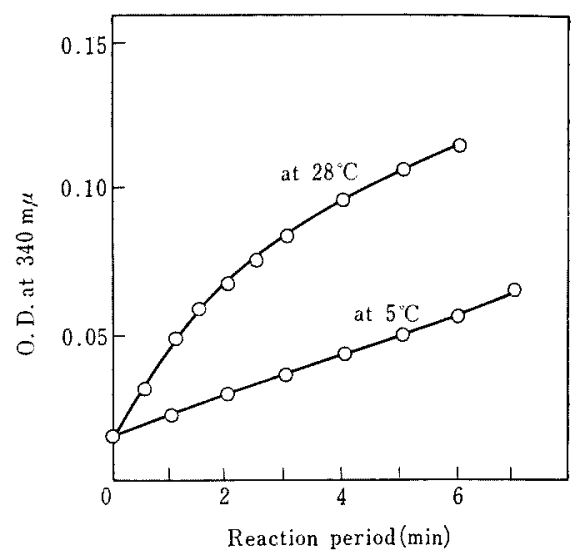

FIG. 3. L-Glutamic Acid Dehydrogenase Activity at $5^{\circ}$ and $28^{\circ} \mathrm{C}$.

Reaction mixture contained $50 \mu$ moles of Lglutamic acid, $1 \mu$ mole of NADP, $200 \mu$ moles of phosphate buffer ( $\mathrm{pH} 8.3$ ) and $3 \mathrm{mg}$ (as protein) of enzyme in total volume of $3.5 \mathrm{ml}$. The enzyme was prepared from cells grown at $5^{\circ} \mathrm{C}$.

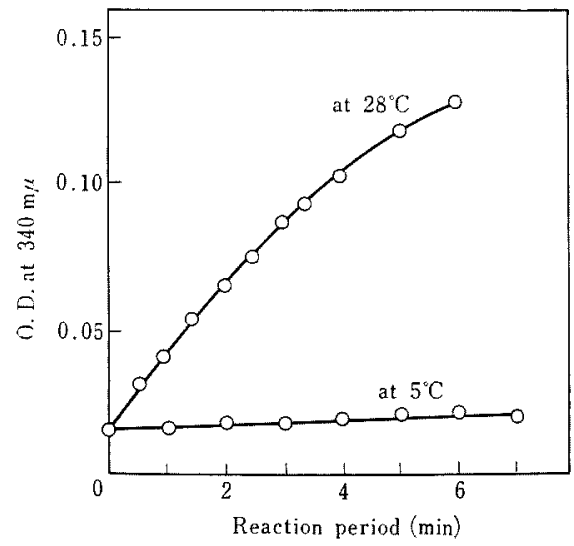

FIG. 4. L-Alanine Dehydrogenase Activity at $5^{\circ}$ and $28^{\circ} \mathrm{C}$.

Reaction mixture contained $50 \mu$ moles of $\mathrm{L}$. alanine, $1 \mu$ mole of NADP, $200 \mu$ moles of phosphate buffer ( $\mathrm{pH} 8.3$ ) and $3 \mathrm{mg}$ (as protein) of enzyme in total volume of $3.5 \mathrm{ml}$. The enzyme was prepared from cells grown at $5^{\circ} \mathrm{C}$.

dehydrogenase activity for L-glutamic acid was observed at both $5^{\circ}$ and $28^{\circ} \mathrm{C}$. On the other hand, L-alanine dehydrogenase activity 
TABLE VI. STOICHIOMETRY OF L-GLUTAMIC AND L-ALANINE DEHYDROGENASES

\begin{tabular}{|c|c|}
\hline $\begin{array}{l}\text { L-Glutamic acid } \\
\text { dehydrogenation de } \\
\mu \text { mole }\end{array}$ & $\begin{array}{l}\text { L-Alanine } \\
\text { hydrogenation } \\
\text { " momole }\end{array}$ \\
\hline NADPH oxidized & 0.32 \\
\hline L-Glutamic acid & L-Alanine \\
\hline Amino acid formed & 0.30 \\
\hline $\begin{array}{l}\text { Oxidation of NADPH was measured } \\
\text { in OD at } 340 \mathrm{~m} \mu \text {. Glutamic acid and } \\
\text { ation were determined by paper ch } \\
\text { method. Reaction mixture contained } \\
\alpha \text {-ketoglutarate or Na-pyruvate, } 120 \mu \text { mo } \\
\mathrm{SO}_{4}, 0.5 \mu \mathrm{mole} \text { of } \mathrm{NADPH}, 200 \mu \text { moles } \\
\text { buffer (pH } 7.8 \text { ) and } 3 \mathrm{mg} \text { (as protein) } \\
\text { total volume of } 3.5 \mathrm{ml} \text {. The reactio } \\
\text { out at } 28^{\circ} \mathrm{C} \text { for } 10 \mathrm{~min} \text {. }\end{array}$ & $\begin{array}{l}\text { by a decrease } \\
\text { alanine form- } \\
\text { aromatographic } \\
50 \mu \text { moles of } \\
\text { les of }\left(\mathrm{NH}_{4}\right)_{2} \text {. } \\
\text { of phosphate } \\
\text { of enzyme in } \\
\text { o was carried }\end{array}$ \\
\hline
\end{tabular}

TABLE VII. SPECIFIC ACtivities of L-Glutamic ACID AND L-ALANINE DEHYDROGENASES AT $5^{\circ}$ AND $28^{\circ} \mathrm{C}$

Enzyme from cells grown

\begin{tabular}{clcccc}
$\begin{array}{c}\text { Reaction } \\
\text { temp. } \\
{ }^{\circ} \mathrm{C}\end{array}$ & Substrate & \multicolumn{2}{c}{$\begin{array}{c}\text { at } 5^{\circ} \mathrm{C} \\
\text { coenzyme }\end{array}$} & \multicolumn{2}{c}{$\begin{array}{c}\text { at } 28^{\circ} \mathrm{C} \\
\text { coenzyme }\end{array}$} \\
& & $\overbrace{\text { NAD }}$ NADP & NAD & NADP \\
5 & L-Glutamate & 0.00 & 8.33 & 0.00 & 8.33 \\
& L-Alanine & 0.00 & 0.00 & 0.00 & 0.00 \\
& L-Glutamate & 0.00 & 41.6 & 0.00 & 36.7 \\
& L-Alanine & 0.00 & 30.0 & 0.00 & 22.1
\end{tabular}

Reaction mixtures were the same as described in Figs. 3 and 4 .

was not apparent at $5^{\circ} \mathrm{C}$ (Fig. 4).

The stoichiometry of the reverse reactions is shown in Table VI which demonstrates that the amount of reduced NADP is approximately equivalent to the amount of L-glutamic acid and L-alanine formed.

Using the cell-free extracts prepared from cells grown at $5^{\circ}$ and $28^{\circ} \mathrm{C}$, the specific activities of both dehydrogenases were determined at $5^{\circ}$ and $28^{\circ} \mathrm{C}$. As for co-enzyme specificity, the enzymes were found to be specific for NADP in the dehydrogenations of both amino acids, but NAD could not replace NADP (Table VII).

As shown in Table VII, regardless of the temperature of the cultivation, the cell-free extract showed the dehydrogenase activities at $28^{\circ} \mathrm{C}$ for both amino acids but at $5^{\circ} \mathrm{C}$, L-alanine dehydrogenase activity was not observed. The extract from cells grown at $5^{\circ} \mathrm{C}$ showed $\mathrm{L}$-alanine dehydrogenase activity in the reaction at $28^{\circ} \mathrm{C}$ but not at $5^{\circ} \mathrm{C}$. It follows from these results that the organism is able to synthesize the enzyme at $5^{\circ} \mathrm{C}$ but is not active at the low temperature. The results obtained at enzyme level are in accord with the information from cultural experiments (Fig. 2-a, b).

Acknowledgement. The authors wish to thank $\mathrm{Dr}$. H. Yamada, Research Institute for Food Science, Kyoto University, and Dr. K. Soda, Institute for Chemical Research, Kyoto University for their valuable discussions throughout this work. 